\title{
Factors that Influence Program Selection and Its Relationship with Students' Achievement in Pre-University Study
}

\author{
Farah Liyana Azizan ${ }^{1}$, Nor Amalina Ahmad ${ }^{1}$, Nur Fazliana Rahim ${ }^{1}$, Rohaiza Daud ${ }^{1}$, Mus Chairil Samani², Mohd \\ Alhafiizh Zailani ${ }^{1}$, Mohd Aminudin Mustapha ${ }^{1}$, Mohamad Fhaizal Mohamad Bukhori ${ }^{1}$, Ahmad Alif Kamal ${ }^{1}$ \\ ${ }^{1}$ Centre for Pre-University Studies, Universiti Malaysia Sarawak, Malaysia \\ ${ }^{2}$ Department of Communication, Faculty of Language and Communication Studies, Universiti Malaysia \\ Sarawak, Malaysia \\ Correspondence: Farah Liyana Azizan, Centre for Pre-University Studies, Universiti Malaysia Sarawak, 94300, \\ Kota Samarahan, Sarawak, Malaysia. E-mail: afliyana@unimas.my
}

Received: July 6, $2017 \quad$ Accepted: July 26, $2017 \quad$ Online Published: August 25, 2017

doi:10.5539/ass.v13n9p145 URL: https://doi.org/10.5539/ass.v13n9p145

\begin{abstract}
The purpose of this study is to recognize the influencing factors in program selection in pre-university level and its relationship with student's achievement. Competition among school leavers to further their studies at a higher level institution is getting tougher; making choosing a program offered by universities becomes a real challenge. After completing secondary school studies, most universities require students to complete a minimum of 1-2 years of post-secondary education before enrolment. Pre-university program is one of the options of post-secondary education. Since the curriculum of pre-university program is very comprehensive, students attending this program have to undergo various challenges throughout their academic sessions. Therefore, students are expected to have their own targets and focus prior to attending any of these studies. In this study, the researchers use a survey to investigate and analyze factors that influence students' decisions in choosing a pre-university program and also the relationship between their decisions making with their academic achievements. The study reveals that all the factors listed significantly influence the students' decision making in choosing a pre-university program. However, not all of these factors are taken into consideration in choosing a program that has a significant relationship with their achievement. Therefore, knowledge derived from this study is beneficial to the Ministry of Higher Education and any higher learning institutions which offer pre-university programs including the policy makers. The knowledge also allows policy makers to plan preemptive action to improve student's performance.
\end{abstract}

Keywords: pre-university, program selection, student's decision, student's achievement

\section{Introduction}

According to Education Act of 1996, the National Education System of Malaysia consists of five levels of education which comprises of pre-school education, primary education, secondary education, post-secondary education, and higher education. Post-secondary education includes the Malaysian Certificate of Higher Education (Sijil Tinggi Pelajaran Malaysia, STPM), diploma, matriculation or pre-university certificate. In pre-university studies, there are two programs offered to students which are Life Sciences (LS) and Physical Sciences (PS). Each program has its own advantages and perspectives as the syllabus in each study is prepared differently based on a university's bachelor degree syllabus. Therefore, students are advised to determine the ideal study program for them to avoid failure as a result of choosing the wrong program.

This study is conducted to determine the factors that influence students' choice of pre-university program. "Pre" means before, therefore, "pre-university" means the course that one has to take before enrolling into a university program. A pre-university program takes between one to two years to complete.

There are many factors that encourage students in the selection of an institution of higher learning. Among these are; the types of courses offered at the university, academic reputation, campus environment, type of university, location, family advice, influence from friends, cost of tuition fees and many others. These factors may affect students' susceptibility in choosing a university. To countless school-leavers, the collection of information in deciding where to continue their studies becomes a real challenge. 
National education system in Malaysia has opened a lot of opportunity for Sijil Tinggi Pelajaran Malaysia (SPM) school leavers to continue their studies at the Institute of Higher Learning (IPTA) or Institute of Higher Learning (IPTS). Rapid development in the field of education also influences the process of selection of students to the university. According to Nadzri Mohammed and Abu Othman Md. Tap (2002), the process of choosing a course of study will become progressively tough as all institutions of higher learning (IPT) offer an extensive range of quality programs and competitive environment for the purpose of attracting the attention of students. Also, when a large number of applicants choose the same program, the competition becomes tougher which makes it harder for the students to make the best choice (Misran et al., 2011).

In this paper, the objectives to be answered are as follows: (i) the factors that students take into consideration in choosing a program of study at pre-university level, (ii) the difference between male and female students' decision making factors in choosing a program of study at pre-university level, and (iii) the relationship between the factors influencing students' choice of pre-university program with their achievement in pre-university.

\section{Literature Review}

High academic achievement is a key priority for every student to continue their studies at a higher level. The environment of higher education has increasingly become competitive because of this. Therefore, the selection of the appropriate program has to be taken into account in ensuring their success in life. There are several factors that influence the students' academic achievement such as aptitude, instruction and environment (Walberg, 1984; Fraser et al., 1987). According to Eidimtas and Juceviciene (2014), students can decide on their studies based on four categories which are educational factors, information factors, economic factors, other factors such as geographical location of a higher education institution and ratings, personal skills and demography.

It is also important to note that courses offered by a university can also affect students' choice. Selection of the appropriate course will have a good influence on the selection of their career in the future. However, a mistake in choosing a course of study can negatively affect the students because they might experience stress due the inability to adapt to the environment and different teaching approaches in universities.

Students should make a choice based on their interest in a course. Interest is an important element and it is different for every student. According to Rhys Davies (2003), a course of study is chosen based on students' interest in a subject. Therefore, every student should consider all aspects before choosing a course in the higher level institution. In addition, other factors that influence the selection of program in pre-university are the rank as well as the reputation of a university. Most students choose a university that has the best expertise in their field of interest and also a university which is recognized by the accreditation bodies to secure a job after graduation.

The location of the university as well as family is also factors that are taken into account by the students in choosing a pre-university program. In addition, they might also be influenced by their family and friends. A study conducted by the School Relations and Diversity Outreach Office and Institutional Research Office (2008) found that peer influence plays a role in helping students decide their path in the institutions of higher learning. However, it is undeniable that there are also some students who choose a university because of advertising and promotion, cost of living and experience and culture.

Von Mizener and William (2011) conducted a study on the effects of student's choice on academic performance and the result showed that the academic performance degraded if the student did not have goals in the selection. Meanwhile, Hemsley-Brown and Oplatka (2015) have categorized the choice factors to demographics, outcomes and benefit, academic, characteristic of institutions, quality, geographical, information sources, price sensitivity. However, according to the common university intake procedure, the students' intake in an institution is based on their choices and minimum requirements of a program that allows them to choose the programs offered. On top of that, the minimum requirements are based solely on the academic and co-curriculum merits instead on students' personalities and interest. Survey using questionnaire is often used to gather data to measure relationship between tendencies, pattern and behavior of studies program selection by the students with factors that encourage students in selecting their area of studies (Fernandez, 2010; Maringe, 2006; Sarrico et al., 1997). Therefore, this study also uses survey to investigate and analyze factors that influence students' decisions in choosing a pre-university program, and also the relationship between the decisions made with their academic achievements in pre-university program.

\section{Methodology}

This study uses an inquisition method for data collection regarding the relation between the trend patterns of student's selection to pre-university and its relationship with students' achievement in pre university study. A total of four hundred $(\mathrm{N}=400)$ students were selected as respondents. Two-hundred of them were male students 
and another two-hundred were female students. Sampling was carried out academically by taking into account their cumulative grade point average (CGPA). Half of the respondents selected for this study obtained 3.00 pointer and above. Meanwhile the other remaining respondents obtained 2.99 pointer and below. Distributed equally according to programs, two-hundred of them were Life Sciences (LS) students while another two-hundred were Physical Sciences (PS) students. The questionnaire distribution and data collection were done twice in 2015/2016 and 2016/2017 sessions to see the consistency of the results.

The instruments used in this study are questionnaires and the students' CGPA. The questionnaires consist of five parts which refer to the five main factors that indicate the students decision making factors. The factors are categorized as personal factor, academic quality, campus, socialization and financial aid. Each factor comprises of several questions related to the objectives of this study. Respondents were requested to answer each question according to the scale given in the provided column to show their agreement to the statements given. A 5-Likert Scale questionnaire were used in this study where each student was offered options of five responses; strongly disagree, disagree, not sure, agree, and strongly agree.

Data obtained from the questionnaires was analyzed by descriptive and inference methods based on the purpose that has been specified using percentage method. The descriptive method focuses on inclination of students' program selection in pre-university study. Meanwhile, inferential analysis involves statistical analysis to define the difference and relationship variables studied based on the hypothesis that has been built. Statistical software package for Social Science (SPSS) version 22.0 was used for analyzing the data in the form of the frequency, percentage and correlation between analyzed data and students' achievement.

\section{Result and discussion}

This section discusses the findings based on three objectives of the research. Data obtained from the questionnaires was analyzed and described in a tabular form. This section consists of two parts, which are analysis data for 2015/2016 session and analysis data for 2016/2017 session. This includes the respondents' information and background followed by the findings obtained by each research objective.

\subsection{Respondents' Information and Details}

In this section, respondents' information obtained involves the students' gender differences, program of study and CGPA. Table 1 and 2 show the distribution of respondents by gender, program of study and CGPA for the whole semester for 2015/2016 and 2016/2017 sessions respectively.

Table 1. Respondents' Information

\begin{tabular}{ccccc}
\hline \multirow{2}{*}{ Sex } & Program of Study & Total (N) & CGPA \\
\cline { 4 - 5 } Male & Life Sciences (LS) & 100 & Above 3.00 & Below 3.00 \\
& Physical Sciences (PS) & 100 & 93 & 107 \\
\multirow{2}{*}{ Female } & Life Sciences (LS) & 100 & 107 & 93 \\
\hline Total & Physical Sciences (PS) & 100 & 200 & 200 \\
\hline
\end{tabular}

Table 2. Respondents' Information

\begin{tabular}{|c|c|c|c|c|}
\hline \multirow{2}{*}{ Sex } & \multirow{2}{*}{ Program of Study } & \multirow{2}{*}{ Total (N) } & \multicolumn{2}{|c|}{ CGPA } \\
\hline & & & Above 3.00 & Below 3.00 \\
\hline \multirow{2}{*}{ Male } & Life Sciences (LS) & 100 & \multirow{2}{*}{98} & \multirow{2}{*}{102} \\
\hline & Physical Sciences (PS) & 100 & & \\
\hline \multirow{2}{*}{ Female } & Life Sciences (LS) & 100 & \multirow{2}{*}{102} & \multirow{2}{*}{98} \\
\hline & Physical Sciences (PS) & 100 & & \\
\hline Total & & 400 & 200 & 200 \\
\hline
\end{tabular}

Table 1 and 2 indicate four-hundred $(\mathrm{N}=400)$ students for each session, in which half of them were from the LS program and half from the PS program. These two-hundred respondents represented one-hundred male and one-hundred female students for each program. The next section is going to discuss the results of this study 
based on the research objectives.

4.1.1 Objective 1: Factors that student takes into consideration in choosing a program of study at pre- university level

There are five factors that have been taken into consideration in choosing a program at pre-university level, which are personal factor, academic quality, campus, socialization and financial aid. Respondents gave their feedback through a survey questionnaire. Table 3 and 4 show the factors that affect their consideration in choosing a pre-university program for 2015/2016 and 2016/2017 sessions.

Table 3. Factors consideration in choosing a program of study

\begin{tabular}{cccc}
\hline Factors & Mean & Mode & Standard Deviation (s.d) \\
\hline Personal Factor & 3.34 & 3.67 & 0.56 \\
Academic Quality & 3.54 & 3.36 & 0.45 \\
Campus & 3.00 & 3.00 & 0.81 \\
Socialization & 3.01 & 2.83 & 0.76 \\
Financial Aid & 3.22 & 3.00 & 0.91 \\
\hline
\end{tabular}

Table 4. Factors consideration in choosing a program of study

\begin{tabular}{cccc}
\hline Factors & Mean & Mode & Standard Deviation (s.d) \\
\hline Personal Factor & 3.08 & 3.60 & 0.90 \\
Academic Quality & 3.36 & 3.42 & 0.53 \\
Campus & 3.00 & 3.00 & 0.77 \\
Socialization & 3.12 & 3.00 & 0.80 \\
Financial Aid & 3.51 & 3.45 & 0.44 \\
\hline
\end{tabular}

Based on the above analysis, for both 2015/2016 and 2016/2017 sessions, it is found that the mean of all the factors is above 3.00. This means that the students agree with all the factors suggested. Other than that, it can be seen that the value of mode for personal factor scored the highest, which are 3.67 and 3.60 respectively. Therefore, it can be concluded that personal factor is an important factor that is taken into consideration by these students in choosing a pre-university program.

\subsection{Hipotesis Test Analysis}

4.2.1 Objective 2: Differences between male and female students' decision making factors in choosing a pre-university program

Table 5 and 6 show the result of t-test analysis for the purpose of identifying whether there is a significant difference between male and female students' decision-making factors in choosing a pre-university program for 2015/2016 and 2016/2017 sessions.

Table 5. Gender Differences in students' decision making factors in choosing a program of study

\begin{tabular}{ccccccc}
\hline & $\mathbf{N}$ & Mean & s.d & $\boldsymbol{t}$ & $\boldsymbol{d f}$ & Sig \\
\hline Factor Choosing & & & & 0.542 & 398 & 0.036 \\
Male & 200 & 3.25 & 0.52 & & & \\
Female & 200 & 3.20 & 0.45 & & & \\
\hline
\end{tabular}

Table 6. Gender Differences in students' decision making factors in choosing a program of study

\begin{tabular}{ccccccc}
\hline & $\mathbf{N}$ & Mean & s.d & $\boldsymbol{t}$ & $\boldsymbol{d f}$ & Sig \\
\hline Factor Choosing & & & & -0.994 & 398 & 0.032 \\
Male & 200 & 3.20 & 0.50 & & & \\
Female & 200 & 3.24 & 0.48 & & & \\
\hline
\end{tabular}


Based on the above tables, it is found that the mean values for male and female students' decision-making factors are 3.25 and 3.20 for 2015/2016 session and 3.20 and 3.24 for 2016/2017 session. This shows that the students agree with all the factors suggested in choosing a pre-university program. The t-test analysis result shows the value of tstat, which equals to 0.036 and 0.032 respectively for 2015/2016 and 2016/2017 sessions. Therefore, it can be concluded that there is a significant difference between male and female decision-making factors in choosing a pre-university program. This indicates that gender difference also affects their decision-making.

4.2.2 Objective 3: Relationship between the factors influencing students' choice of pre-university program with their achievement in pre-university program

The research proceeds with the correlation analysis. Table 7 and 8 below show the correlation between the tendencies of decision making with their achievement in pre-university program in 2015/2016 and 2016/2017 sessions.

Table 7. Correlation between the tendencies of choosing program and their achievement in pre university program

\begin{tabular}{ccc}
\hline & & CGPA \\
\hline \multirow{2}{*}{ Personal Factor } & Pearson Correlation & 0.06 \\
& Sig. (2-sample) & 0.23 \\
\hline Academic Quality & Pearson Correlation & 0.08 \\
& Sig. (2-sample) & 0.11 \\
\hline \multirow{2}{*}{ Campus and Facilities } & & 0.01 \\
& Pearson Correlation & 0.86 \\
\hline Socialization & Sig. (2-sample) & -0.07 \\
& Pearson Correlation & 0.19 \\
\hline Financial Aid & Sig. (2-sample) & 0.12 \\
& Pearson Correlation & 0.02 \\
\hline
\end{tabular}

Table 8. Correlation between the tendencies of choosing program and their achievement in pre university program

\begin{tabular}{ccc}
\hline & & CGPA \\
\hline Personal Factor & Pearson Correlation & 0.04 \\
& Sig. (2-sample) & 0.46 \\
\hline Academic Quality & Pearson Correlation & -0.03 \\
& Sig. (2-sample) & 0.50 \\
\hline Campus and Facilities & Pearson Correlation & -0.08 \\
& Sig. (2-sample) & 0.13 \\
\hline Socialization & Pearson Correlation & -0.10 \\
& Sig. (2-sample) & 0.04 \\
\hline Financial Aid & Pearson Correlation & -0.05 \\
& Sig. (2-sample) & 0.29 \\
\hline
\end{tabular}

Based on the analysis above, the data shows the correlation between the tendencies of decision making with their achievement in pre-university program. For 2015/2016 session, it can be see that the result of correlation analysis shows that there is a relationship between financial aid factor with students' achievement, where the value of $r=0.12$ and the value of $p=0.02$ which is less than significant level, 0.05 . While the other factor shows no relationship between students' achievement. For 2016/2017 session, the result of correlation analysis shows that there is a relationship between socialization factor with students' achievement, where the value of $r=-0.10$ and the value of $\mathrm{p}=0.04$ which is less than significant level, 0.05 . While the other factor shows no relationship between students' achievement. So, it can be concluded that some of the tendencies of decision making do affect their achievement in pre-university program. Even though the mean value for each factor is above 3.00, it does not indicate that they have a good achievement. 


\section{Conclusion}

Based on all the results that have been discussed, it can be concluded that all of these factors do affect the students' decision-making in choosing a program of study in pre-university level. The results also show that there is a significant difference in the factors that affect decisions made by male and female students. In addition, the results also indicate that not all these factors have significant relationships with their achievement in pre-university program.

\section{Acknowledgement}

The project was funded by the research grant C09(S180)/1324/2016(4) Small Grant Scheme UNIMAS.

\section{References}

Barries to Enrollment: High School Students' Perception of what it will take to go to college (2008). School of Relation and Diversity Outreach Office and Institutional Research Office.

Eidimtas, A. \& Juceviciene, P. (2014). Factors influencing school-leavers decision to enroll in higher education. Procedia - Social and Behavioral Sciences, Vol. 116, 3983 - 3988. https://doi.org/10.1016/j.sbspro.2014.01.877

Fernandez, J. L. (2010). An exploratory study of factors influencing the decision of students to study at Universiti Sains Malaysia. Kajian Malaysia, 28(2), 107.

Fraser, B. J., Walberg, H. J., Welch, W. W. and Hattie, J. A. (1987). Syntheses of educational productivity research. International Journal of Education Research, 11, 145-252. https://doi.org/10.1016/0883-0355(87)90035-8

Hemsley-Brown, J \& Oplatka, I (2015), University choice: what do we know, what don't we know and what do we still need to find out?, International Journal of Educational Management, 29(3), 254-74. https://doi.org/10.1108/IJEM-10-2013-0150

Maringe, F. (2006). University and course choice: Implications for positioning, recruitment and marketing.

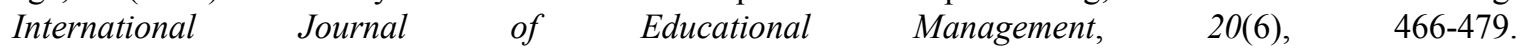
https://doi.org/10.1108/09513540610683711

Misran, N., Aziz, N. A., Arshad, N., Hussain, H., Zaki, W. M. D. W., \& Sahuri, S. N. S. (2011). Influencing factors of matriculation students in selecting university and program of study. Procedia - Social and Behavioral Sciences, 60, 567-574. https://doi.org/10.1016/j.sbspro.2012.09.424

Nadzri bin Mohamad, Abu Othman bin Md. Tap (2002). Keutamaan pemilihan bidang dan tempat pengajian: pendekatan conjoin kabur, dalam journal teknologi maklumat dan sains kuantitatif. Universiti Teknologi Mara.

Rhys Davies, (2003). Dropping Out: A study of Early Leavers From Higher Education. Department for education and skill. Norwich.

Sarrico, C. S., Hogan, S. M., Dyson, R. G. and Athanassopoulos, A. D. (1997). Data envelopment analysis and university selection. Journal of the Operational Research Society, 48, 1163-1177. DOI: 10.2307/3010747

Von Mizener, B. H., \& Williams, R. L. (2011). The effects of student choices on academic performance. Journal of Positive Behavior Interventions, 11(2), 110-128. Retrieved from http://www.pbi.sagepub.com; http://dx.doi.org/10.1177/1098300708323372

Walberg, H. J. (1984). Improving the productivity of America's schools. Educational Leadership, 41(8), 19-27.

\section{Copyrights}

Copyright for this article is retained by the author(s), with first publication rights granted to the journal.

This is an open-access article distributed under the terms and conditions of the Creative Commons Attribution license (http://creativecommons.org/licenses/by/4.0/). 